\title{
PENERAPAN METODE TWO STAY TWO STRAY YANG DIVARIASIKAN DENGAN LKS WORD SQUARE UNTUK MENINGKATKAN HASIL BELAJAR SISWA SMA NEGERI 2 TANJUNG SELOR
}

\author{
SENITA LUSIANA MANGNGA' \\ SMA Negeri 2 Tanjung Selor, Kalimantan Utara \\ e-mail: senitalusiana@gmail.com
}

\begin{abstract}
ABSTRAK
Berdasarkan observasi awal di SMA Negeri 2 Tanjung Selor, diketahui bahwa hasil belajar peserta didik kelas X MIPA 2 masih relatif rendah. Hal ini dapat dilihat dari ketuntasan belajar klasikal pada data awal kelas X MIPA 2 untuk mata pelajaran Biologi sebesar 41\%. Hasil belajar yang masih rendah ini disebabkan oleh metode pembelajaran yang diterapkan masih menggunakan metode ceramah (metode konvensional). Metode ini membentuk peserta didik menjadi pasif dan kurang kreatif sehingga perlu adanya model pembelajaran yang membuat peserta didik menjadi aktif. Model pembelajaran yang dapat diterapkan untuk lebih dapat mengaktifkan peserta didik salah satunya adalah model pembelajaran Two Stay Two Stray yang divariasikan dengan LKS Word Square. Jenis penelitian ini adalah Penelitian Tindakan Kelas (PTK). Tujuan dari penelitian ini adalah untuk mengetahui peningkatan belajar materi Keanekaragaman Hayati melalui penerapan metode Two Stay Two Stray yang divariasikan dengan LKS Word Square di kelas X MIPA 2 SMA Negeri 2 Tanjung Selor. Subjek penelitian ini adalah kelas X MIPA 2 SMA Negeri 2 Tanjung Selor dengan jumlah siswa 22 orang. Penelitian ini dilaksanakan dalam dua siklus. Tiap siklus terdiri dari 4 tahap yaitu: perencanaan, pelaksanaan, observasi, dan refleksi. Indikator keberhasilan penelitian ini adalah (1) peningkatan persentase siswa yang memperoleh nilai $\geq 70$ atau jumlah peserta didik yang belajar tuntas meningkat menjadi 95\%, (2) ketuntasan keaktifan klasikal $\geq 85 \%$. Berdasarkan hasil penelitian dapat disimpulkan bahwa penerapan metode Two Stay Two Stray yang divariasikan dengan LKS Word Square dapat meningkatkan hasil belajar biologi siswa kelas X MIPA 2 SMA Negeri 2 Tanjung Selor pada pokok bahasan Keanekaragaman Hayati. Peningkatan ini ditandai dengan hasil persentase kenaikan pencapaian ketuntasan belajar klasikal pada siklus I sebesar $59 \%$ dan pada siklus II mencapai $95 \%$.
\end{abstract}

Kata Kunci: Metode Two Stay Two Stray, LKS Word Square, Hasil Belajar.

\section{PENDAHULUAN}

Pembelajaran IPA adalah pembelajaran yang tidak mengabaikan hakikat IPA dan mencerminkan sifat IPA sebagai ilmu pengetahuan alam. IPA adalah body knowledge. IPA adalah suatu cabang pengetahuan yang mengangkat fakta-fakta yang tersusun secara sistematis dan menunjukkan berlakunya hukum-hukum umum. IPA merupakan pengetahuan yang didapat dengan jalan study dan praktik. IPA juga dapat diartikan sebagai suatu cabang study yang bersangkut-paut dengan observasi dan klasifikasi fakta-fakta terutama dengan disusunnya hukum umum dengan induksi dan hipotesis (Subiyanto, 1998:2). Pembelajaran IPA memiliki peran penting untuk perkembangan peserta didik menjadi manusia yang memahami alam sekitar dan perannya dalam kehidupan manusia. Peserta didik jelas menikmati manfaat dari pembelajaran IPA bagi perkembangan potensi dirinya jika pembelajarannya berhasil.

Biologi adalah sebagai salah satu cabang dari ilmu pengetahuan alam (IPA) yang mempelajari tentang mahluk hidup dan lingkungan sekitarnya. Karena biologi merupakan salah satu cabang dari IPA, maka biologi tidak akan lepas dari hakikat IPA (Susanto, 2002). Biologi bukan hanya kumpulan fakta dan konsep, karena di dalam biologi juga terdapat berbagai proses nilai yang dapat dikembangkan dan diaplikasikan dalam kehidupan sehari-hari (Saptono, 2003:56). Pembelajaran biologi seharusnya dapat menampung kesenangan dan kepuasan intelektual peserta didik dalam usahanya untuk menggali berbagai konsep pengetahuan, selain itu juga merupakan proses penemuan. Pendidikan biologi diharapkan dapat menjadi wahana 
bagi peserta didik untuk mempelajari diri sendiri dan alam sekitar serta prospek pengembangan lebih lanjut dalam menerapkannya di dalam kehidupan sehari-hari. Penyelenggaraaan pendidikan akan dapat berhasil apabila semua unsur dalam sistem pembelajaran berjalan seiring dan seirama menuju tujuan pendidikan yang ditetapkan. Dengan demikian pembelajaran biologi harus bertumpu pada dua hal yaitu optimalisasi interaksi semua unsur pembelajaran dan optimalisasi keterlibatan seluruh siswa dalam pembelajaran.

Kenyataan yang banyak dijumpai di lapangan adalah pembelajaran Biologi yang masih berpusat pada guru sebagai pemberi pengetahuan bagi siswa, penyampaian materi pelajarannya cenderung masih didominasi dengan ceramah (metode konvensional). Siswa kurang berperan aktif dalam proses pembelajaran untuk membangun dan menemukan sendiri melalui interaksi dengan lingkungannya, sehingga siswa hanya manghafalkan fakta-fakta dari buku dan bukan dari hasil menemukan serta membangun sendiri pengetahuannya. Berdasarkan hasil study intensif mengenai pola pembelajaran dan pehamaman siswa, disimpulkan bahwa pembelajaran cenderung text book oriented yang tidak terkait dengan kehidupan sehari-hari (Suhandini, 2003). Pada dasarnya tidak semua siswa bermasalah pada saat guru menerangkan pelajaran dengan menggunakan metode ceramah. Namun terkesan hanya siswa yang berada di bangku paling depan saja $( \pm 25 \%)$ yang memperhatikan pelajaran dengan baik sehingga kelas terkesan di dominasi oleh siswa-siswa yang mempunyai kemampuan diatas rata-rata dan siswa cenderung bersikap individual. Pada proses pembelajaran dengan metode ceramah siswa biasanya kurang aktif dalam pelaksanaan proses belajar sehingga kelas terkesan kurang terkoordinir dengan baik. Melalui metode ceramah ini siswa terkesan bosan, ngantuk, dan tidak memperhatikan penjelasan yang disampaikan guru. Siswa tidak aktif bertanya ataupun mengemukakan pendapatnya $( \pm 75 \%)$ sehingga informasi hanya berjalan satu arah yaitu dari guru kepada peserta didik.

Berdasarkan hasil observasi pada tanggal 23 dan 26 Agustus 2019 di SMAN 2 Tanjung Selor dikelas X MIPA 2, dapat diketahui bahwa pembelajaran dikelas masih berpusat pada guru (teacher centre). Guru menjelaskan materi didepan kelas dengan metode ceramah (metode konvensional). Kegiatan peserta didik hanya duduk mendengarkan dan mencatat materi yang disampaikan guru. Dalam pembelajaran tersebut, terlihat siswa masih kurang termotivasi untuk belajar, tidak berani menjawab maupun mengajukan pertanyaan pada guru, hal ini tampak saat guru memberikan pertanyaan hanya beberapa siswa yang berani untuk menjawab dan ketika guru memberikan kesempatan pada siswa untuk bertanya, sebagian besar siswa cenderung diam.

Model pembelajaran yang digunakan guru cenderung kurang membangkitkan semangat peserta didik untuk berpartisipasi aktif dalam pembelajaran. Akibatnya terlihat beberapa peserta didik ada yang bercanda dengan teman, mengantuk dan melamun. Interaksi antar peserta didik dan antara guru dengan peserta didik relatif masih kurang. Hal ini menunjukkan sikap dan motivasi peserta didik dalam pembelajaran biologi masih rendah. Sehingga, iklim pembelajaran dikelas menjadi kurang kondusif. Untuk itu diperlukan suatu upaya yang dapat meningkatkan efektivitas belajar peserta didik. Upaya untuk meningkatkan kualitas pembelajaran adalah melalui metode yang bervariasi dan sesuai dengan materi. Alasannya adalah : (1) dengan metode pembelajaran yang tepat dapat membantu siswa dalam memahami materi, (2) metode pembelajaran dipandang sebagai salah satu unsur penting dalam rangka mencapai tujuan pengajaran. Penggunaan metode yang tepat akan membuat proses pembelajaran menjadi lebih efektif karena dengan metode yang tepat peserta didik akan mampu memahami materi pelajaran dengan lebih mudah. Metode pembelajaran merupakan alat untuk mencapai tujuan pengajaran yang ingin dicapai sehingga penggunaan metode yang baik dan tepat akan semakin berhasil sebagai sarana pencapaian tujuan.

Berdasarkan permasalahan tersebut, salah satu alternatif pemecahan masalah yaitu dengan menerapkan metode Two Stay Two Stray yang divariasikan dengan LKS Word Square. Penerapan model pembelajaran ini diharapkan peserta didik terlibat aktif dalam proses pembelajaran, kondisi belajar menjadi lebih menyenangkan dan hasil belajar Biologi akan 
meningkat. Catharina Tri Anni (2007) menjelaskan bahwa "hasil belajar merupakan perilaku yang diperoleh pembelajar setelah mengalami aktivitas belajar". Hasil belajar mempunyai peranan penting dalam proses pembelajaran. Proses penilaian terahadap hasil belajar dapat memberikan informasi kepada guru tentang seberapa jauh kemajuan peserta didik dalam upaya mencapai tujuan belajarnya melalui kegiatan belajar.

Model pembelajaran Two Stay Two Stray atau dua tinggal dua tamu dikembangkan oleh Spencer Kagan (1992). "Struktur dua tinggal dua tamu memberikan kesempatan kepada kelompok untuk membagikan hasil dan informasi dengan kelompok lain" (Lie dalam Shoimin, 2014:222). Kelebihan dari metode Two Stay Two Stray adalah dapat diterapkan pada semua kelas/tingkatan, kecenderungan belajar siswa menjadi lebih bermakna, lebih berorientasi pada keaktifan, membantu meningkatkan minat dan prestasi belajar, memberikan kesempatan kepada kelompok untuk membagikan hasil dan informasi ke kelompok lain (Anita Lie, 2008: 61). Dengan demikian peserta didik dalam belajar biologi tidak hanya mendengarkan saja, namun memerlukan keaktifan peserta didik didalam prosses belajar mengajar, sehingga dapat memberikan pengaruh dalam meningkatkan kualitas pembelajaran biologi. LKS Word Square merupakan salah satu alat bantu berupa kotak-kotak kata yang berisi kumpulan huruf. Pada kumpulan huruf tersebut terkandung materi-materi yang harus ditemukan oleh siswa sesuai dengan pertanyaan yang berorientasi pada tujuan pembelajaran (Aqib: 2013:31). Kelebihan LKS Word Square cenderung menggali pengetahuan peserta didik dan menarik minat peserta didik untuk menggunakan buku sebagai sumber belajar biologi, dan juga merupakan salah satu media pembelajaran yang didalamnya terdapat unsur permainan, sehingga peserta didik tidak merasa bosan sehingga dapat menarik minat dan menambah motivasi belajar peserta didik.

Berdasarkan uraian latar belakang diatas, maka guru sebagai peneliti tertarik untuk melaksanakan penelitian dengan judul "Penerapan Metode Two Stay Two Stray yang Divariasikan dengan LKS Word Square untuk Meningkatkan Hasil Belajar Siswa SMA Negeri 2 Tanjung Selor".

\section{METODE PENELITIAN}

Penelitian ini merupakan jenis penelitian tindakan kelas (PTK), pada penelitian ini terdiri dari dua siklus, dimana jika pada siklus I tidak berhasil akan dilanjutkan pada siklus II, dan jika siklus II tidak berhasil maka akan dilanjutkan pada siklus III yang masing-masing terdiri dari empat tahap seperti yang dikemukakan Tim Penyusun PGSM (1999:7), yaitu: 1) Merencanakan Tindakan, 2) Melakukan Tindakan, 3) Mengamati, dan 4) Merefleksi. Setelah melakukan refleksi yang mencakup analisis dan penilaian terhadap proses serta hasil tindakan akan direncanakan tindakan baru untuk siklus berikutnya. Tindakan ditunjukkan untuk memperbaiki hal-hal yang kurang atau mempertahankan hal-hal yang dirasa cukup baik. Subjek penelitian adalah siswa kelas X MIPA 2 SMA Negeri 2 Tanjung Selor yang berjumlah 22 orang.

Instrumen yang digunakan dalam penelitian ini terdiri dari 3 yaitu (1) Lembar Kerja Siswa (LKS) Word Square, LKS ini digunakan peserta didik untuk kerja kelompok dan ketika diskusi berlangsung, dengan tujuan untuk mengetahui seberapa besar peran serta dan kinerja tiap-tiap kelompok dan masing-masing peserta didik ketika proses pembelajaran berlangsung, (2) Tes hasil belajar, tes yang dilaksanakan sebanyak dua kali yaitu pada akhir siklus I dan akhir siklus II, tes digunakan untuk mengetahui hasil belajar peserta didik yang menggambarkan pemahaman peserta didik terhadap konsep biologi yang telah dipelajari, (3) Catatan Lapangan, digunakan untuk mencatat segala bentuk kegiatan yang ditampakkan oleh peserta didik atau hal-hal yang terkait dengan penelitian misalnya mengenai nama-nama peserta didik yang tidak masuk, situasi saat kegiatan belajar sedang berlangsung, peserta didik yang membuat gaduh dan ramai, serta peserta didik yang pasif atau pendiam, selain itu juga sebagai media pencatat ada beberapa peserta didik yang aktif, memperhatikan serta menyimak suatu pelajaran pada saat diberikan.

Berdasarkan gambaran umum penelitian sebagaimana disebutkan di atas, akan dilaksanakan PTK dengan prosedur seperti disajikan pada gambar 1. 


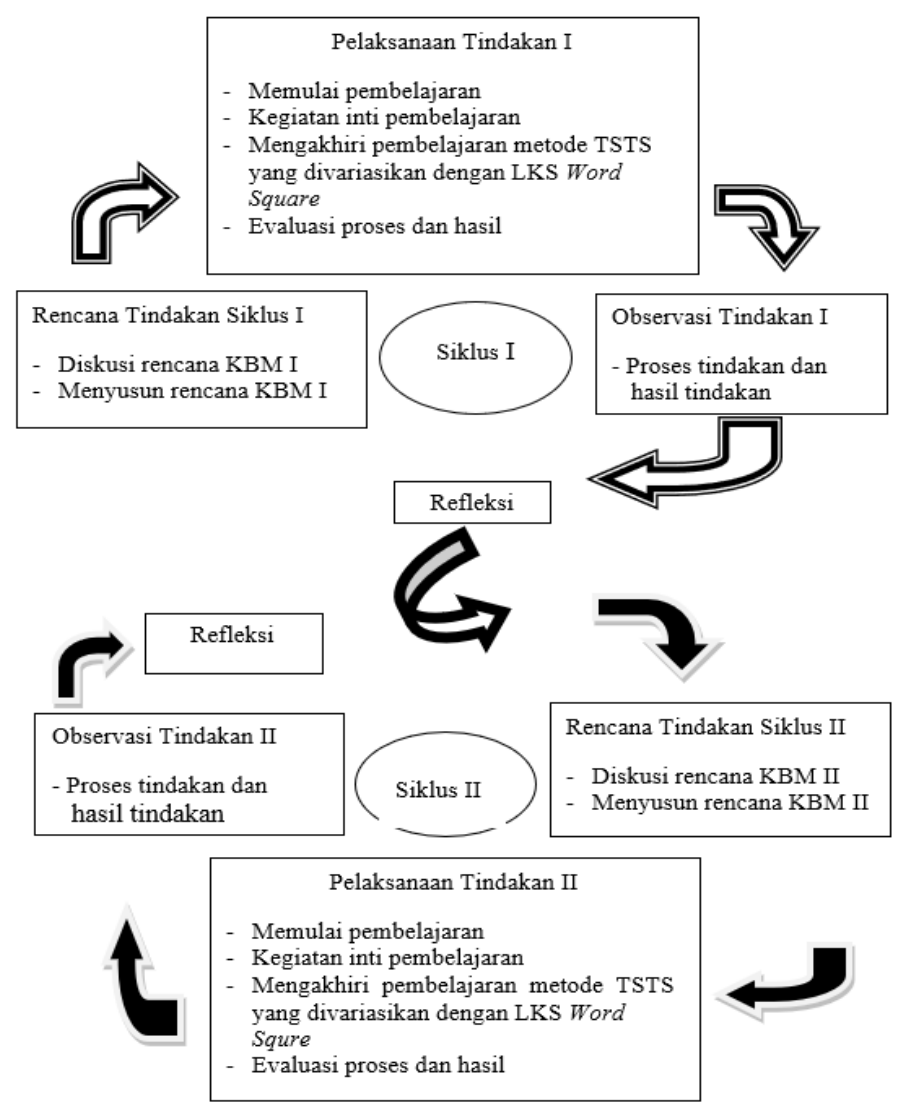

Gambar 1. Prosedur Pelaksanaan PTK

Sesuai dengan gambar diatas, maka Siklus I terdiri dari 4 tahap yaitu, tahap (1) Perencanaan tindakan, pada tahap ini peneliti mempersiapkan perangkat pembelajaran (membuat RPP, membagi siswa dalam kelompok, menyusun LKS dan jawaban dan menyusun instrumen penelitian dengan berdiskusi dengan teman sejawat. Tahap (2) Pelaksanaan Tindakan, pada tahap ini peneliti melaksanakan kegiatan belajar mengajar sesuai dengan RPP yang telah disusun sebelumnya. Tahap (3) Observasi, kegiatan ini dilakukan bersama dengan pelaksanaan pembelajaran. Pada tahap ini, data-data tentang pelaksanaan tindakan dari rencana yang sudah dibuat serta dampaknya terhadap proses dan hasil pembelajaran dikumpulkan dengan alat bantu instrumen pengamatan yang telah dikembangkan. Observasi dilakukan untuk mengetahui kelemahan dan kelebihan dari pelaksanaan tindakan yang akan digunakan sebagai acuan dalam tindakan berikutnya. Tahap (4) Refleksi dilakukan untuk melihat keseluruhan proses pelaksanaan tindakan dan hasil pemahaman konsep peserta didik. Refleksi merupakan kegiatan menganalisis, memahami, dan membuat kesimpulan berdasarkan hasil pengamatan dan hasil tes. Jika telah tercapai maka siklus berhenti, tetapi bila belum berhasil maka peneliti melakukan pengulangan siklus dengan perbaikan-perbaikan yang dianggap perlu pada siklus II.

Pelaksanaan siklus II meliputi perencanaan tindakan, pelaksanaan tindakan, pengamatan tindakan (observasi), dan refleksi tindakan yang merupakan perbaikan hasil yang dicapai pada siklus I. Urutan tahapan kegiatan yang dilakukan sama dengan yang telah dilakukan pada siklus I tetapi dengan mempertahankan tindakan yang mampu meningkatkan hasil belajar, atau dengan memperbaiki tindakan apabila terjadi kekurangan pada siklus I dan diakhri dengan pemberian tes hasil belajar. 


\section{HASIL DAN PEMBAHASAN}

\section{Hasil Penelitian}

\section{a. Pencapaian Siklus I}

Pelaksanaan belajar biologi pada siklus I dilaksanakan pada tanggal 24 September 2019. Pada akhir tindakan siklus I peserta didik diberi test siklus I, untuk mengetahui bagaimana pencapaian standart ketuntasan belajar peserta didik setelah dilakukan penerapan pembelajaran dengan menggunakan metode Two Stay Two Stray yang divariasikan dengan LKS Word Square. Dari hasil penelitian, pencapaian kriteria ketuntasan minimal disajikan pada tabel 1.

Tabel 1. Pencapaian KKM Siklus I

\begin{tabular}{lcc}
\hline \multicolumn{3}{c}{ Pencapaian KKM } \\
\hline & $\begin{array}{l}\text { Sebelum } \\
\text { tindakan }\end{array}$ & Data Siklus I \\
\hline Jumlah peserta didik yang tuntas & 9 & 13 \\
Jumlah peserta didik yang tidak tuntas & 13 & 9 \\
Rata-rata nilai & 64,3 & 79,7 \\
Persentase (\%) yang tuntas & $41 \%$ & $59 \%$ \\
Persentase (\%) yang tidak tuntas & $59 \%$ & $41 \%$ \\
\hline
\end{tabular}

Berdasarkan tabel 1. di atas dapat diketahui ketuntasan belajar peserta didik secara klasikal, kriteria ketuntasan minimal (KKM) yang digunakan yaitu 70, sebelum dilakukan tindakan maka dapat dketahui bahwa peserta didik yang dikatakan tuntas secara individu ada 9 dengan presentase secara klasikal $41 \%$ peserta didik dan yang lainnya belum tuntas, secara klasikal 59\% dengan nilai rata-rata 64,3. Setelah dilakukan tindakan siklus I yaitu penerapan metode pembelajaran Two Stay Two Stray yang divariasikan dengan LKS Word Square dan peserta didik diberikan test siklus I, peserta didik yang dikatakan tuntas secara individu ada 13 peserta didik dan 9 peserta didik belum tuntas dengan ketuntasan klasikal $59 \%$ dan rata-rata nilai 79,7, karena ketuntasan secara klasikal belum mencapai persentase $\geq 85 \%$, oleh karena itu perlu dilanjutkan ke siklus II. Sebelum melanjutkan ke siklus II, peneliti melakukan refleksi yaitu dengan memetakan kendala-kendala yang dihadapi selama siklus I, yang tersaji pada tabel 2.

Tabel 2. Refleksi untuk dilaksanakan pada siklus II

\begin{tabular}{|c|c|c|}
\hline Aspek & Kendala & Rekomendasi \\
\hline \multirow[t]{3}{*}{ Hasil belajar } & $\begin{array}{l}\text { Psikis peserta didik, } \\
\text { motivasi belajar, } \\
\text { minat dan perhatian } \\
\text { peserta didik kurang }\end{array}$ & $\begin{array}{lr}\text { Guru } & \text { lebih } \\
\text { memotivasi peserta } \\
\text { didik, memberi } \\
\text { penguatan, mengelola } \\
\text { kelas dan membuat } \\
\text { suasana pembelajaran } \\
\text { yang menyenangkan. }\end{array}$ \\
\hline & $\begin{array}{l}\text { Peserta didik kurang } \\
\text { memahami dan } \\
\text { melaksanakan } \\
\text { intruksi dari guru. }\end{array}$ & $\begin{array}{l}\text { Guru pandai } \\
\text { mengkomunikasikan } \\
\text { langkah-langkah } \\
\text { pembelajaran dengan } \\
\text { bahasa yang mudah } \\
\text { dan dipahami peserta } \\
\text { didik. }\end{array}$ \\
\hline & $\begin{array}{l}\text { Kekurangkompakan } \\
\text { anggota kelompok. }\end{array}$ & 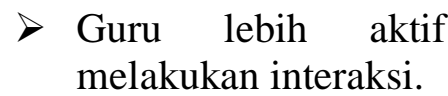 \\
\hline
\end{tabular}




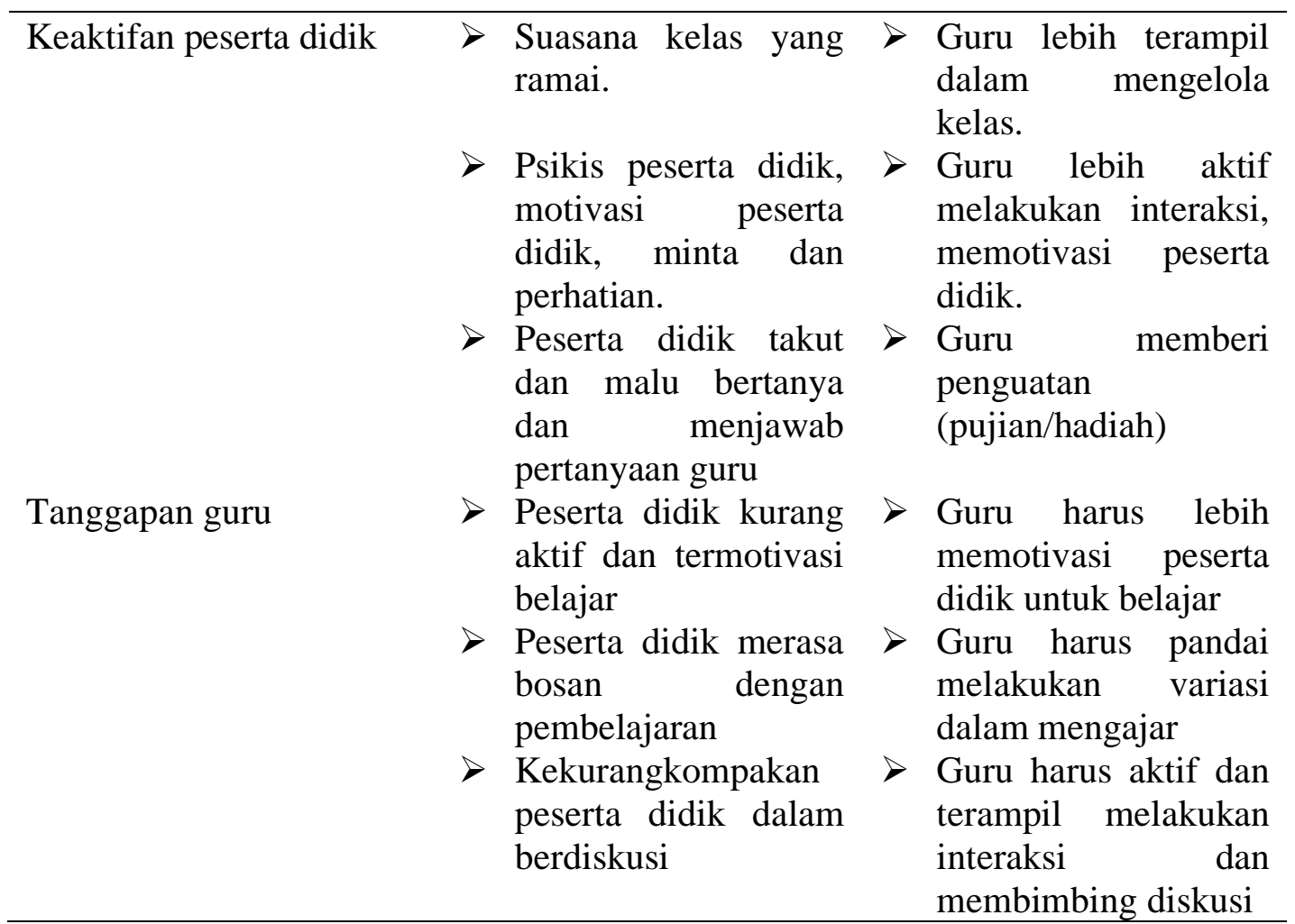

\section{b. Pencapaian Siklus II}

Pelaksanaan belajar biologi pada siklus I dilaksanakan pada tanggal 8 Oktober 2019. Pada akhir tindakan siklus II peserta didik diberi test siklus II, untuk mengetahui bagaimana pencapaian kriteria ketuntasan minimal peserta didik setelah dilakukan penerapan pembelajaran dengan menggunakan metode Two Stay Two Stray yang divariasikan dengan LKS Word Square, yang tersaji pada Tabel 3.

Tabel 3. Pencapaian KKM siklus II

\begin{tabular}{lll}
\hline \multicolumn{3}{c}{ Pencapaian KKM } \\
\hline Jumlah peserta didik yang tuntas & Data siklus I & Data siklus II \\
Jumlah peserta didik yang tidak tuntas & 13 & 21 \\
Rata-rata nilai & 9 & 1 \\
Presentase (\%) yang tuntas & 79,7 & 89,4 \\
Presentase (\%) yang tidak tuntas & $59 \%$ & $95 \%$ \\
\hline
\end{tabular}




\section{Gambar 2. Grafik Pencapaian Hasil Belajar Siklus I dan II}

Berdasarkan pada tabel 3 dan gambar 2 di atas, dapat diketahui bahwa hasil belajar peserta didik kelas X MIPA 2 yang mengikuti pembelajaran metode Two Stay Two Stray yang divariasikan dengan LKS Word Square pada siklus I diperoleh nilai rata-rata hasil belajar biologi 79,7 dan ketuntasan belajar 59\% atau ada 13 peserta didik dari 22 peserta didik sudah tuntas belajar, dan 9 peserta didik belum tuntas belajar (41\%). Tetapi setelah dilakukan perbaikan-perbaikan tindakan pada siklus II diperoleh nilai rata-rata hasil belajar biologi 89,4, dan ketuntasan belajar $95 \%$ atau ada 21 peserta didik dari 22 peserta didik sudah tuntas belajar, dan 1 orang peserta didik belum tuntas belajar (5\%). Hasil ini menunjukkan bahwa secara klasikal peserta didik sudah tuntas belajar, dan sudah memenuhi syarat karena jumlah peserta didik yang telah mencapai nilai $\geq 70(\mathrm{KKM})$ sebanyak $95 \%$ dan berada diatas kriteria ketuntasan klasikal $\geq 85 \%$. Terjadi peningkatan sebesar 9,7\% dari rata-rata nilai 79,7 pada siklus menjadi 89,4 pada siklus II, sedangkan pada ketuntasan klasikal terjadi peningkatan sebesar $36 \%$ dari ketuntasan klasikal 59\% pada siklus I menjadi 95\% pada siklus II, maka penelitian ini berakhir pada siklus kedua.

\section{Pembahasan}

Peningkatan hasil belajar akan dapat dicapai apabila peserta didik diberikan kesempatan untuk mengikuti proses belajar dan mengalami sendiri secara utuh dari setiap kegiatan pembelajaran, dengan demikian pencapaian hasil belajar berkaitan erat dengan proses belajar yang dialami peserta didik. Sebaliknya jika proses belajar mengajar berlangsung dalam keadaan kurang kondusif maka pada akhirnya akan berdampak terhadap rata-rata hasil belajar peserta didik.

Penelitian ini membuktikan bahwa terdapat pengaruh yang signifikan terhadap penerapan metode Two Stay Two Stray yang divariasikan dengan LKS Word Square terhadap hasil belajar peserta didik, hal ni sesuai dengan pendapat Satrijono (2012) metode merupakan suatu faktor penentu dalam keberhasilan belajar pada proses pengajaran. Sebelum penerapan metode pembelajaran dapat diketahui bahwa kentuntasan belajar peserta didik masih rendah yaitu $41 \%$. Setelah melaksanakan proses pembelajaran, pada akhir siklus I dilaksanakan evaluasi pembelajaran. Perolehan nilai rata-rata peserta didik adalah 79,7, dimana ada 3 peserta didik yang memperoleh nilai 100 dan sedangkan nilai terendah yang diperoleh peserta didik adalah 40 sebanyak satu peserta didik. Secara umum dapat disimpulkan bahwa penelitian tindakan kelas yang dilaksanakan pada siklus I sudah mengalami perubahan karena sebanyak $59 \%$ peserta didik yang tuntas belajar, ini juga membuktikan bahwa penggunaan media dapat 
meningkatkan hasil belajar peserta didik, karena merasa senang dalam mengerjakan LKS Word Square hal ini sependapat dengan Safarini (2010:22) yaitu word square dapat meningkatkan keaktifan dan keterlibatan peserta didik dalam kegiatan karean selalu diikuti diskusi atau penjelasan guru serta memotivasi belajar peserta didik yang pada akhirnya dapat meningkatkan hasil belajar, namum belum mencapai target ketuntasan klasikal minimal 85\%, oleh karena itu peneliti melanjutkan tindakan pada siklus II.

Kurang maksimalnya tingkat kentuntasan belajar klasikal pada siklus I antara lain disebabkan oleh adanya beberapa kendala dalam proses belajar mengajar, yaitu kurang keterlibatan peserta didik secara aktif dalam proses belajar mengajar. Hal tersebut dibuktikan dengan masih ragu-ragunya peserta didik untuk berperan aktif dalam proses pembelajaran, misalnya melalui pengajuan pertanyaan, menjawab pertanyaan guru dengan benar, maupun untuk mengungkapkan pendapat atau ide-ide terkait materi pelajaran yang disampaikan oleh guru.

Berdasarkan hasil analisis pada siklus I masih terdapat kekurangan dalam pengelolaan kelas oleh guru dan hasil belajar yang belum memenuhi indikator keberhasilan sehingga perlu diadakan perbaikan pada proses pembelajaran berikutnya, yaitu guru harus lebih mendorong peserta didik untuk berpartisipasi aktif dalam kegiatan diskusi sehingga soal- soal dalam lembar kerja dapat mereka pahami dan akhirnya menemukan jawaban dengan benar sehinga dapat meningkatkan pemahaman dan hasil belajar peserta didik, selain itu kondisi kelas akan lebih aktif yang memungkingkan materi yang disampaikan oleh guru dapat diserap dengan baik dan cepat.

Pembelajaran pada siklus II dilaksanakan dengan tujuan untuk lebih mengaktifkan peserta didik dalam kegiatan diskusi. Proses pembelajaran biologi Keanekaragaman Hayati melalui model Two Stay Two Stray yang divariasikan dengan LKS Word Square mengedepankan keterampilan peserta didik dalam mencari informasi dan dapat dibagikan kepada teman kelompoknya dan juga kepada kelompok yang lain. Evaluasi terhadap hasil belajar peserta didik diberikan pada akhir siklus II. Perolehan nilai rata-rata peserta didik sebesar 89,4 dengan ketuntasan belajar secara klasikal sebesar 95\%. Secara umum dapat disimpulkan bahwa hasil penelitian tindakan kelas yang dilaksanakan pada siklus II, untuk ketuntasan secara klasikal termasuk kedalam kategori sangat baik karena mampu mencapai 95\%. Persentase kentuntasan klasikal ini telah melewati standar ketuntasan klasikal minimal $85 \%$, dengan telah tercapainya hasil tersebut maka penelitian ini dihentikan. Walaupun secara klasikal ketuntasan belajar sudah tercapai namun secara individual berdasarkan analisis hasil belajar peserta didik yang mengalami penurunan sebanyak 2 peserta didik , tetap 4 peserta didik dan naik sebanyak 16 peserta didik. Hal ini disebakan oleh adanya faktor internal yang berasal dari dalam diri peserta didik meliputi dua aspek yaitu aspek fisiologis yang bersifat jasmaniah dan aspek psikologis yang meliputi tingkat kecerdasan, sikap peserta didik, bakat peserta didik. Faktor ini dipandang turut meningkatkan tingkat keberhasilan belajar peserta didik.

Meningkatnya hasil belajar peserta didik dari siklus I ke siklus II menunjukkan terjadinya pemahaman terhadap materi yang dipelajari, peserta didik lebih berani bertanya dan mengungkapkan pendapat. Peningkatan keaktifan peserta didik dari siklus I ke siklus II menyebabkan hasil belajar pada siklus II meningkat. Peningkatan rata-rata kelas dan jumlah peserta didik yang belajar tuntas ini menunjukkan adanya pemahaman peserta didik terhadap materi pembelajaran meningkat. Kenyataan ini sesuai dengan pendapat Nurhadi (2004) yang menyatakan bahwa siswa akan belajar dengan baik apabila mereka terlibat secara aktif dalam segala kegiatan di kelas dan berkesempatan untuk menemukan sendiri.

Selama pelaksanaan pembelajaran pada siklus I dan siklus II, dari hasil pengamatan dapat diketahui telah terjadi perubahan pada peserta didik ke arah yang lebih baik, ini dapat kita lihat dari presentase ketuntasan klasikal yang telah dicapai, yang mana tujuan utama dari pelaksanaan pembelajaran di sini adalah untuk meningkatkan hasil belajar peserta didik. Hasil yang diperoleh dari penelitian ini ternyata sama dengan penelitian sebelumnya yaitu penelitian 
yang dilakukan Wijana dkk (2004) menyatakan bahwa model pembelajaran Two Stay Two Stray dapat meningkatkan hasil belajar IPA peserta didik.

\section{KESIMPULAN}

Berdasarkan hasil analisis data penelitian dan pembahasan, maka dapat disimpulkan bahwa penerapan metode Two Stay Two Stray yang divariasikan dengan LKS Word Square pada siklus I ketuntasan belajar klasikal peserta didik sebesar 59\% dengan nilai rata-rata 74,7. Pada siklus II ketuntasan belajar klasikal peserta didik sebesar 95\% dengan nilai rata-rata 89,4. Dengan demikian metode Two Stay Two Stray yang divariasikan dengan LKS Word Square dalam pembelajaran kooperatif efektif dapat meningkatkan hasil belajar peserta didik. Dengan hasil penelitian ini, penulis mengharapkan guru dapat menggunakan metode ini untuk materi pembelajaran biologi lainnya karena metode ini akan memudahkan peserta didik dalam memahami materi.

\section{DAFTAR PUSTAKA}

Aqib.Z. (2003). Model-Model, Media, dan Strategi Pembelajaran Kontekstual (Inovatif). Bandung: Yrama Widya.

Catharina. (2006). Psikologi Belajar. Semarang: Unnes Press.

Lie, Anita. (2008). Cooperative Learning. Jakarta : PT Gramedia Widiasarana.

Nurhadi. (2004). Pembelajaran Kontekstual dan Penerapannya Dalam KBK. Malang: UM Press.

Safarini, F. (2010). Efektifitas Metode Word Square Dalam Penguasaan Kosakata Verba Bahasa Jepang. (Skripsi). Bandung:Universitas Pendidikan Indonesia.

Saptono, S. (2003). Strategi Belajar Mengajar Biologi. Semarang: Universitas Negeri Semarang.

Satrijono, H. (2012). Penerapan pembelajaran kooperatif dengan teknik dua tinggal dua bertamu (two stay two stray). Jurnal Ilmu Pendidikan Sekolah Dasar. Vol.1, No. 2, Hlm. 166-182.

Shoimin, A. (2014). 68 Model Pembelajaran Inovatif dalam Kurikulum 2013. Yogyakarta: ArRuzz Media.

Subiyanto. (1998). Pendidikan Ilmu Pengetahuan Alam. Jakarta : Depdikbud.

Suhandini, P. (2003). Pembelajaran Kontekstual dalam Kurikulum Berbasis Kompetensi

dan Manajemen Berbasis Sekolah. Makalah disampaikan dalam Seminar dan Lokakarya Nasional 29 April 2003.

Susanto, P. (2002). Keterampilan Dasar Mengajar IPA Berbasis Konstruktivisme. Malang: UM.

Tim Pelatih Proyek PGSM. (1999). Penelitian Tindakan Kelas. Bahan Pelatihan Dosen LPTK dan Guru Sekolah Menengah, Jakarta: Departemen Pendidikan dan Kebudayaan Dikti Proyek Pengembangan Guru Sekolah Menengah.

Wijana, I K. A. (2014). Pengaruh Model Pembelajaran Kooperatif Teknik Two Stay Two Stray (TSTS) Terhadap Hasil Belajar IPA Pada Siswa Kelas V SD di Desa Kaliasem Kecamatan Banjar Semester Genap Tahun Pelajaran 2013/2014. e-Jurnal Mimbar PGSD Universitas Pendidikan Ganesha. Vol. 2, No. 1. 